\title{
Spiritual, Emotional and Cultural Homelessness - Comments from Own Research on the Axiological Condition of Contemporary Man
}

\author{
Mgr Katarzyna Lisowska \\ Czasopismo Naukowe, Edukacja Etyczna
}

Streszczenie:

Bezdomność zaczyna się w rodzinie. Jest to nie tylko kategoria kondycji fizycznej, dotyczy ona przede wszystkim procesów psychicznych. Może mieć również charakter emocjonalny, duchowy lub kulturowy. Bezdomność jest stanem niedostatku, jak wspomniano powyżej, jest synonimem samotności.

Słowa kluczowe: Bezdomność, bezdomność emocjonalna, bezdomność kulturowa, bezdomność duchowa, samotność.

\section{Wprowadzenie}

Bezdomność jest przede wszystkim stanem psychicznym, który charakteryzuje się oderwaniem od wspólnoty społecznej, wartości jej życia, głównie poczucia bezpieczeństwa. Człowiek bezdomny jest człowiekiem nawet nie samotnym, ale osamotnionym, to znaczy wyrwanym z kontekstu relacji z innymi, bliskich, emocjonalnych więzi, które są nam niezbędne do życia jako istotom społecznym.

Sytuacja bezdomności jest stanem ekstremalnym, oznacza brak podstawowych warunków do życia, pozbawienie egzystencjalnej przestrzeni. Człowiek bezdomny jest sam, na ulicy, zmaga się o to, by przetrwać, jednakże funkcjonuje w chronicznej niemożliwości realizacji nie tylko potrzeb bytowych, ale i psychicznych.

Bezdomność jest osamotnieniem, stanem obumierania, śmierci społecznej. Kryterium określającym sytuację bezdomności jest stan chroniczny, w jakim jednostka pozbawiona jest miejsca zamieszkania ${ }^{1}$.

Bezdomność zaczyna się w rodzinie. Jest procesem, zdarzają się jednak sytuacje nagłe, które skutkują bezdomnością. Bezdomność nie jest tylko kategorią stanu fizycznego, przede wszystkim odnosi się do psychologicznych procesów. Może mieć charakter także emocjonalny, duchowy czy kulturowy. Bezdomność jest stanem braku, niedostatku, jak wspomniano, jest tożsama $\mathrm{z}$ osamotnieniem.

Człowiek bezdomny odczuwa pustkę, nie znajduje wartości życia społecznego, które mogą okazać się na tyle tworzące jego życie, że jest w stanie poradzić sobie z odczuwanymi stanami braków. Czasami taki dotkliwy rodzaj bezdomności emocjonalnej (bezdomność pierwotna), braku osadzenia w relacjach z innymi - przechodzi w bardziej złożoną fazę bezdomności, gdzie jednostka zaczyna funkcjonować na ulicy (bezdomność wtórna).

Człowiek odczuwający emocjonalne braki, wynikające z jakości relacji z innymi - łatwo sprowadza swoje życie do kategorii funkcjonowania $\mathrm{w}$ stanie uzależnień, od alkoholu, innych substancji odurzających. Uzależnić można się też od nowych technologii. Przebywanie w wirtualnej

\footnotetext{
${ }^{1}$ B. Moraczewska, Bezdomność. Definicja, problemy, rozwiąania obecne oraz historyczne odwołanie do ludzi luźnych, „Studia Gdańskie. Wizje i rzeczywistość”, t. X,

http://www.gwsh.gda.pl/uploads/oryginal/3/3/5a4a8_113-128_Moraczewska.pdf [Dostęp: 23.01.2021].
} 
rzeczywistości jest wyrazem dotkliwej pustki człowieka, bezdomności emocjonalnej, w jakiej poszukuje się alternatywnej rzeczywistości. Ten stan blokuje realizuję autentycznych potrzeb ludzkich. Miejsce każdego człowieka jest we wspólnocie. Rodzina daje człowiekowi poczucie bliskości i ocala go przed zatraceniem w różnych formach bezdomności, w jakich dokonują się regresywne zmiany.

\section{Przyczyny bezdomności}

Nie istnieje uniwersalna definicja bezdomności, stąd jak zauważa Agata Woźniak-Krakowian, bezdomność można rozpatrywać na wielu płaszczyznach, jako zjawisko społeczne, bardzo trudny problem. Na bezdomność możemy patrzeć jak na sytuację życiową człowieka lub stan patologiczny. Ludzie bezdomni przeżywają problemy egzystencjalne i w pierwszej kolejności pomoc koncentruje się na tym, by rozwiązać trudne sytuacje w tej sferze bytu².

W Polsce dopiero od latach 80. i 90. XX wieku zaczęto używać terminu bezdomność. Wówczas nastąpił wzrost przypadków osób, jakie zamieszkiwały na dworcach, klatkach schodowych czy w parkach.

Człowiek bezdomny nie może sobie pomóc, sam nie jest w stanie wyjść z bezdomności, zapewnić sobie mieszkania. Osoba bezdomna nie ma wpływu na to, że nie przysługuje jej przestrzeń do życia, która spełnia choć minimalne standardy mieszkaniowe ${ }^{3}$. Współcześnie rozrasta się problem nie tylko bezdomności, która sprowadza się do braku miejsca zamieszkania, godnych warunków bytowych. Ludzie są bezdomni, osamotnieni w swoich rodzinach, oderwani od funkcjonowania $\mathrm{w}$ bliskich relacjach na dużą skalę. Aktualnie rodziny w dużej mierze są bezdomne z powodu braku miłości. Ludzie są bezdomni aksjologicznie, duchowo, kulturowo, poszukują sensu życia, czują się w swoim życiu wyobcowani i pozbawieni nadziei na zmianę sytuacji mentalnej, która paraliżuje ich egzystencję. Niepokojąco wzrasta liczba samobójstw, już wśród dzieci odnotowuje się fale depresji. To wszystko stany tożsame z bezdomnością, z którymi bardzo trudno sobie poradzić samodzielnie, bez odpowiedniego wsparcia emocjonalnego. Tylko drugi człowiek, jego obecność, zbliżenie się do człowieka osamotnionego może spowodować, że jednostka będzie odradzała się społecznie, zacznie funkcjonować w bliskich relacjach, które są sensem życia człowieka jako jednostki społecznej.

Beata Szluz zauważa, że bezdomność wciąż nie jest właściwie zbadana, a problem jest bardzo duży. Autorka uważa, że problem bezdomności jest nawet zagrożeniem w poznawaniu przez badacza ${ }^{4}$. Za mało wiemy, poza tym prowadząc badania terenowe - ludzie mają obawy, by wyjść na spotkanie komu? Człowiekowi pokrzywdzonemu, który przede wszystkim stracił do innych zaufanie, oddalił się. Boimy się bezdomności, nie chcemy nawet o niej myśleć. Trudno nam spojrzeć na człowieka bezdomnego.

Ks. Śledzianowski zauważył, że każdy człowiek bezdomny prawie ma jakąś rodzinę, kogoś formalnie bliskiego. Ludzie trafiają na ulice ze swoich domów, gdzie jest obojętność, chłód emocjonalny, nie ma miłości, są konflikty, brak zrozumienia, wsparcia. Człowiek zaczyna być bezdomny w swojej rodzinie. Dostrzegamy natomiast bezdomność dopiero wówczas, gdy jednostka jest pozbawiona środków do życia. Bezdomność trwa znacznie wcześniej.

\section{Przesłanie św. Brata Alberta}

Św. Brat Albert kierował się troską o godność każdego człowieka. Ten sposób myślenia o człowieku pozwala nam zbliżyć się do niego, nie bać się jego krzywdy, cierpienia, niedostatku. Są ludzie, jacy

\footnotetext{
2 A. Woźniak-Krakowian, Bezdomność i jej problemy, http://dlibra.bg.ajd.czest.pl:8080/Content/1866/13.pdf [Dostęp: 23.01.2021].

${ }^{3}$ Ibidem.

${ }^{4}$ B. Szluz, Bezdomność rodzin - socjologiczny szkic problemu, „Rocznik Nauk Społecznych”, tom 3, 2011 , s. 139.
} 
boją się, że człowiek ubogi o coś poprosi. Łatwiej większości ludzi zbliżyć się do człowieka smutnego i samotnego, może chcieć rozmowy, obecności. Jednak wiele osób czuje się bezsilnych, gdy druga osoba prosi o wsparcia, którego potrzebuje, by przeżyć. Zarazem chodzi zawsze o coś więcej, o co ludzie bezdomni wstydzą się najbardziej prosić, to są ludzie odruchy, emocje, dobre słowo. Człowiek potrzebuje miłości, która jest sensem jego istnienia, funkcjonowania w relacjach społecznych, wsparcia i oparcia. Obecność drugiego człowieka jest najbardziej leczniczą formą pomocy, to największe ofiarowanie - swojego czasu, dobroci, zainteresowania. Ludziom bezdomnym można pomagać odpowiednio wcześnie, starczy nie być obojętnym, gdy obserwujemy dramaty samotności, że ktoś jest w naszym otoczeniu opuszczony, nie czuje oparcia innych.

Bezdomność dzieje się niezależnie od posiadanych środków. Trudno spotkać ludzi bezdomnych w małych miejscowościach, bo ludzie tworzą bliższe relacje. Bezdomność jest tam, gdzie człowiek czuje się anonimowy. Może pozwolić sobie na to, by w ukryciu rozwijać sposoby radzenia sobie z rzeczywistością, w jakich sięga się po alkohol, destruktywny seks, pozbawiony uczyć i wiele innych wyborów, które sprawiają, że ludzie czują pustkę, także pokrzywdzenie i samotność.

Bezdomność zaczyna się od samotności w rodzinie, gdy człowiek ma poczucie, że ma czas, ma inne wartości, ale nie ma komu ofiarować swojej troski, zaangażowania. Zaczynają się poszukiwania alternatywnych form spędzania czasu, pojawia się potrzeba szukania nowych wrażeń, coraz silniejszych, w efekcie potęguje się stan znieczulenia. Zarazem człowiek dezintegruje się, pozornie czuje się pusty emocjonalnie. To stan pozorny, wyciszenia, jest to rodzaj wyczerpania emocjonalnego. Ów stan prowadzi do tego, że człowiek chce poczuć się lepiej, znieczulić swoje bóle egzystencjalne, lęki. Zarazem chce poczuć coś prawdziwego i intensywnego. Ludzie bezdomni emocjonalnie inwestują w powierzchowne relacje, które jeszcze przez chwilę trzymają ich przy życiu, jakie zdaje się normalne.

\section{Studia przypadków}

A. jest kobietą, młodego pokolenia, nie wyjawia, ile ma lat. Opowiada, że czuje, iż jej życie przebiega $w$ fazie uśpienia. To ma znaczyć, że wstaje rano, wykonuje swoje obowiązki, przymusza się do tego, utrzymuje pożądany poziom aktywności. Radzi sobie w pracy z obowiązkami. Nie skupia się na życiu prywatnym. Nie chce inwestować w relację emocjonalną, nie chce tracić zasobów psychicznych. Ważne jest dla niej, by skupić się na pracy, która nie daje jej satysfakcji. Zarabia, czuje samotność. Nie ma w życiu satysfakcji. Dni zapełnia obowiązkami. Znieczuliła się emocjonalnie. Ma wrażenie, że nie ma w niej emocji, to czasami czuje, że jest na skraju, na granicy załamania, ale opanowała zdolność, by nie wchodzić bardziej w te emocje:

Tak się dziś żyje, pełno ludzi dookoła, a człowiek sam musi liczyć na siebie, sam musi radzić sobie we wszystkim, sam dostaje od siebie pomoc. Trzeba pracować, utrzymać się. Tragedia to nie mieć środków na życie. Nie mogę sobie pozwolić na bierność. Codziennie idę do przodu, dużo pracuję, a tak jakby się nic nie zmieniało. Starzeję się tylko, coraz mniej wierzę w to, że umiem kogoś pokochać i nie mam czasu, bo muszę pracować. Wokół są ludzie nastawieni na cel, chcą mieć pewne życie, ułożyć się. Moi znajomi zbierają na mieszkanie, na lepsze samochody. Realizują kursy, podnoszą kwalifikacje, stale zarabiają więcej. Już wcale się nie widujemy. Piszemy do siebie, $\mathrm{z}$ pracy. Codziennie komunikujemy sobie, że jesteśmy zmęczeni, ale trzeba pracować. W weekend sprawa wygląda tak samo. Do niedawna czekało się na weekend. Obecnie wszyscy dookoła pracują, nie mają czasu, uważają, że trzeba się poświęcić, bo się chce podnieść standard życia i mieć środki na wszystko. W zasadzie nie ma nic, tylko są jakieś środki, których szkoda wydać, bo się pracuje codziennie, siedem dni w tygodniu. Nie liczą się nawet już rozrywki. Jest praca i coraz więcej pracy. Jest pewność przez to najbliższego czasu, że można sobie na parę rzeczy pozwolić, ale takich zwyczajnych. Trzeba być oszczędnym, życie jest drogie. Trzeba być racjonalnym, co do wymagań 
życiowych też. Chodzi o jakość życia, ale jakoś psychicznie ona tylko spada, choć nawet środków do życia jest więcej, to pytanie, jak żyć...

A. nie chce podawać nawet swojego imienia. Czuje, że opanowała sprawy życiowe, elementarne, jest niezależna, pracuje na swoje utrzymanie, uznaje to za jakieś wartości istotne, by liczyć na siebue. Uważa, że musi pracować regularnie, by zapewnić sobie środki do życia, normalność. Wie, że jej życie uległo spłyceniu, zredukowała relacje, nie ma czasu dla siebie, dla innych, nie ma przy sobie rodziny. Jej życie straciło wartości, nie daje jej bowiem większego komfortu psychicznego i realizacji poza poczuciem, że przez to, iż dużo pracuje jest w stanie utrzymać standard życia, przeciętny.

K., kolejna, młoda kobieta inwestuje wiele czasu w edukację, uważa, że trzeba iść ciągle do przodu. Wchodzi w czwartą dekadę życia. Sądzi, że wszystko do życia ma, ale wymusza na sobie poczucie, że warto żyć, w zasadzie uważa, że jak się żyje to żyć trzeba. Nie uważa, że coś jeszcze należy dodać do tych informacji, stara się więcej nie myśleć na te tematy. Szuka impulsu, który przeniesie jej życie na inny poziom. Podejrzewa, że inwestycja w rozwój relacji może zmienić jej odczuwanie życia, jednak jest przekonana, że ludzi nie można blisko dopuścić do siebie, nie ufa im.

Powyższe sytuacje życia pokazują obecne przemiany, zachodzące szybko. Ludzie inwestują w swój rozwój i środki na życie, ale nie żyją, boją się zbliżyć do siebie i boją się nawet odważyć szukać wartości, to może ranić i wymuszać duże siły do wielkich zmian, a jednak bezpieczeństwo to naczelna wartość. Człowiek współczesny rozwija kulturę bezdomności, do tego prowadzi indywidualizm. Zubożamy się emocjonalnie, redukujemy potrzeby, szczególnie emocjonalne, bo chcemy być niezależni, nie chcemy doświadczać w relacjach bólu, traumy, nie chcemy się zawieść. Bezdomność jest stanem redukującym nasze potrzeby i nieco na chwilę lęki. Dziś człowiek potrafi mieć środki na życie, zabezpiecza się na lata, jednak wokół niego jest pusto. Brakuje przestrzeni społecznej - jest to istota bezdomności emocjonalnej.

\section{Bibliografia}

1. Moraczewska B., Bezdomność. Definicja, problemy, rozwiazania obecne oraz historyczne odwołanie do ludzi luźnych, „Studia Gdańskie. Wizje i rzeczywistość”, t. X,

2. http://www.gwsh.gda.pl/uploads/oryginal/3/3/5a4a8_113-128_Moraczewska.pdf

3. Woźniak-Krakowian A., Bezdomność $i$ jej problemy, http://dlibra.bg.ajd.czest.pl:8080/ Content/1866/13.pdf

4. Szluz B. (2011), Bezdomność rodzin - socjologiczny szkic problemu, „Rocznik Nauk Społecznych", tom 3. 